\title{
An overview to the investigative approach to species testing in wildlife forensic science
}

\author{
Adrian Linacre ${ }^{1 *}$, Shanan S Tobe ${ }^{2}$
}

\begin{abstract}
The extent of wildlife crime is unknown but it is on the increase and has observable effects with the dramatic decline in many species of flora and fauna. The growing awareness of this area of criminal activity is reflected in the increase in research papers on animal DNA testing, either for the identification of species or for the genetic linkage of a sample to a particular organism. This review focuses on the use of species testing in wildlife crime investigations. Species identification relies primarily on genetic loci within the mitochondrial genome; focusing on the cytochrome $b$ and cytochrome oxidase 1 genes. The use of cytochrome $b$ gained early prominence in species identification through its use in taxonomic and phylogenetic studies, while the gene sequence for cytochrome oxidase was adopted by the Barcode for Life research group. This review compares how these two loci are used in species identification with respect to wildlife crime investigations. As more forensic science laboratories undertake work in the wildlife area, it is important that the quality of work is of the highest standard and that the conclusions reached are based on scientific principles. A key issue in reporting on the identification of a particular species is a knowledge of both the intraspecies variation and the possible overlap of sequence variation from one species to that of a closely related species. Recent data showing this degree of genetic separation in mammalian species will allow greater confidence when preparing a report on an alleged event where the identification of the species is of prime importance. The aim of this review is to illustrate aspects of species testing in wild life forensic science and to explain how a knowledge of genetic variation at the genus and species level can aid in the reporting of results.
\end{abstract}

\section{Scope of wildlife crime}

Wildlife crime takes many forms from trafficking in live specimens, hunting out of season, cruelty to animals, habitat destruction, poaching for meat, poaching for trophies, poaching to use animal parts in medicines, horns and tusks used for jewellery and ornaments - the list goes on. The scope of wildlife crime covers a wide range of diverse crimes and for this reason many newspaper articles, as well as journal papers, will often cite figures such as:

'The illegal trade in wildlife is a $\$ 20$ billion a year industry, second only to trade in illegal drugs'.

The monetary figure will often range between 6 and 20 billion US dollars a year and the figure is often cited to Interpol [1]. However, Interpol have confirmed that this statement did not come from them. While this

\footnotetext{
* Correspondence: adrian.linacre@flinders.edu.au

'South Australia Justice Chair in Forensic Science, School of Biological

Sciences, Flinders University, Adelaide, South Australia, Australia

Full list of author information is available at the end of the article
}

seems to be a fabricated figure, it is difficult to estimate the exact amount of illegal trade as there are not the same international surveillance teams that are used for drug enforcement for the prosecution of offences involving wildlife. Organized crime has not been proven to be linked to wildlife crime but there are indications that this is the case [2]. Another influencing factor in wildlife crime is that there is a high financial return with little chance of being caught and, even if the perpetrators are caught, the penalties are light. Rarely does the maximum penalty for the alleged event meet the potential financial gains [3].

According to a recent census by the World Wildlife Fund only 3200 tigers (Panthera tigris spp.) exist in the wild [4]. This is a reduction of over $90 \%$ in the last century which has lead to more tigers existing in captivity in Texas than exist worldwide in the wild. Similarly, the population of black rhino (Diceros bicornis) decreased by 96\% between 1970 and 1992 [5]. In 1970, it was estimated that there were approximately 65,000 black

\section{C) Biomed Central}


rhinos in Africa - but, by 1993, there were only 2300 surviving in the wild. Intensive anti-poaching efforts have had encouraging results since 1996. The numbers of black rhino have been recovering and still are increasing very slowly; there are now an estimated wild population of 4420.

The above examples illustrate the affect of trade on the numbers for the tiger and rhino populations. The biological material that is traded is not the whole animal but body parts such as skin, bone or powdered horn. Other examples of mammalian species that are part of the illegal trade in wildlife include elephant ivory [6-10], bear bile [11] and deer products [12-14]. Mammalian species are high profile in the public perception but the trade in reptiles and amphibians is much higher, partly because these species are smaller and therefore easier to conceal in order to avoid detection [15].

A paradox to the limited prosecutions is the rise in interest in the forensic community in wildlife forensic science. There have been reviews of the subject [16-19], a text book on non-human DNA [20] and on wildlife forensic science [21]. There are more publications on non-human DNA in the international journal Forensic Science International: Genetics than papers on topics such as single nucleotide polymorphisms, mixtures or low template DNA typing [22]. Given this interest, it is noteworthy that there are very few laboratories dedicated to wildlife forensic science; the major exception being the US Fish and Wildlife Laboratory http://www. lab.fws.gov in Oregon, USA.

\section{Forensic science relating to wildlife crime}

There are two prime issues that are addressed in wildlife crime and these relate to the phrasing of the different types of legislation. The first being the ability to identify a particular species and the second is the ability to determine whether the biological material can be assigned with confidence to a particular individual member of that species. This review focuses on this first issue.

The reason for determining a particular species is that many species are listed as being protected both at a national and international level. There are currently 175 countries that are signatories to the Convention for the International Trade in Endangered Species of Flora and Fauna (CITES) - an organization that oversees the movement of protected and endangered species across international borders $[23,24]$. Each member country is responsible for the implementation of the Convention at a national level. National legislation has been enacted in many countries which is specifically aimed at the protection of species within their own country. Examples include the Endangered Species Act 1973 in the USA [25], which covers alleged crimes at a federal level. Such all encompassing legislation may include additions and amendments, such as the Wildlife and Countryside Act 1981 in the UK [26] with amendments in 1985 [27] and 1991 [28], with further legislation covering deer [29], seal [30] and badger [31]. Prosecutors are tasked with investigating any alleged transgression of the legislation and, hence, require a scientific test in order to identify a particular species. The test employed depends on the material seized and the funds available for conducting the test. As much of the trade in endangered species originates in countries where funds to enforce any crime are limited, the prosecution of wildlife crime can be given a low priority.

Morphology and microscopy are the natural starting points in identification [32]. This depends on the sample seized but there is little point in requesting molecular testing if the material seized is clearly that of a tiger skin, a section of elephant ivory or a specific shell of a tortoise. Morphological analysis of parts of an animal, or even a live specimen, will often have to be undertaken by a specialist, often from a zoo or a museum. Microscopy of hairs is another skill requiring much experience in order to be able to identify with a high degree of confidence that the material is, for instance, that of a protected species such as the Tibetan antelope (Pantholops hodgsonii), which is protected and CITES listed, compared to those species that are not protected. However, even with experience, a microscopic comparison of hairs may not yield a definitive identification. In Moore's key for the identification of animal hairs, dog appears in over 10 categories and most identifications finish in a group of organisms (for example, camel or dog or llama group) [33]. Much material that is traded is not in a condition where species identification can be made by microscopy or morphology - for instance, the material may present as powders, potions and oils. Biochemical and molecular methods using antibodies or DNA are the tools that can assist with such investigations.

\section{Role of DNA}

The application of DNA-based technologies to the investigation of wildlife crime has opened up the possibility of examining trace material [32]. For instance, in a case where microscopy was used for the putative identification of the Tibetan antelope from woven shawls, the identification to species level can be conducted using DNA typing [34] where the results are not based on the subjective judgement of the examiner. One problem is the associated cost of DNA profiling compared to microscopy. The DNA-based methods used in wildlife crime investigations were adapted from those used in human identification and, in the case of species identification, from taxonomic and phylogenetic studies. For several reasons, the DNA loci used in species testing are 
located on the mitochondrial genome rather than being nuclear DNA based. Mitochondrial DNA typing has become a standard process in species testing, allowing inter-laboratory comparison and permitting a means to standardize methodologies.

The mitochondrial genome in eukaryotes encodes a total of 37 genes, 22 of which encode transfer RNA (tRNA) molecules, two encode ribosomal RNA (rRNA) molecules and the other 13 encode proteins involved primarily with the process of oxidative respiration [35]. The number of genes on the mitochondrial genome is largely invariant for all vertebrate mitochondrial genomes but the order of the genes may alter [36]. The order of the loci on the mitochondrial genome is the same within mammalian species but can differ between taxonomic classes: for instance the order is different between avian and mammalian mitochondrial genomes. Vertebrate mitochondrial DNA has two strands of different buoyant densities: the heavy or $\mathrm{H}$-strand and the light or L-strand. The H-strand is the sense strand for one protein-coding gene (ND6) and eight tRNA genes. The L-strand is the sense strand for 12 protein-coding genes, two rRNA genes and 14 tRNA genes [37].

A major reason for using mitochondrial DNA (mtDNA) loci is that there is no recombination of mtDNA. All maternal descendents will have the same mitochondrial DNA sequence, with the exception of mutations, and all loci will be linked $[38,39]$. There is little DNA on the mtDNA that is non-coding, nor are there introns or pseudogenes within the mammalian mtDNA [36]. With all the coding sections of the mitochondrial genome coding for proteins or RNA molecules involved in respiration, it would be expected that there would be conservation of sequence as any change in the proteins or RNA molecules could adversely affect the organism. Unlike the nucleus, no error reading enzyme exists in the mitochondria to correct DNA bases added incorrectly during DNA replication [40]. Therefore, the accumulation of single base changes is up to five times higher in mtDNA compared to errors due to DNA replication in nuclear DNA.

Additionally, there are multiple copies of mitochondrial DNA per cell compared to only two copies of nuclear DNA [41]. Within each cell there are multiple mitochondria depending on cell type and within each mitochondrion there are multiple copies of mtDNA [42]. The result is that there can be many thousands of mtDNA copies in each cell [42]. Mitochondria have a protein coat that helps protect the mtDNA from degradation. Highly degraded biological material is therefore more likely to be amenable to mtDNA typing compared to the need to generate a DNA profile from nuclear DNA when typing teeth $[43,44]$, bone $[45,46]$ or hair shafts $[47,48]$. Ancient DNA studies have centred on
mtDNA for this purpose with such techniques being familiar to the forensic science community for identification of human remains $[49,50]$. Similarly mtDNA typing is used in mass disasters such as 9/11 [51].

\section{Gene loci used in taxonomy}

The genetic loci of choice for forensic species identification are based on those derived from taxonomic and phylogenetic studies, and are primarily found on the mitochondrial genome [52]. Within mtDNA some gene sequences are thought to exhibit little intraspecific (within members of the same species) variability, but show sufficient interspecific (between different species) variation to allow for an estimation of degrees of relatedness and divergence times via calibrated molecular clocks. The main locus used in taxonomic and phylogenetic studies until recently was cytochrome $b$ (cyt $b$ ) [53-55] which occurs between bases 14,747 and 15,887 in human mtDNA [56] and encodes a protein 380 amino acids in length. The cyt $b$ locus has been used extensively in taxonomic and forensic studies [57-60], including tiger body parts [61-63], turtle eggs and shells [64-66], crocodile skins [67], rhino horn [68], elephant ivory [6], peafowl [69] and bear bile $[11,63]$.

More recently, the use of cytochrome c oxidase I (COI) has increased owing primarily to its adoption by the Barcode for Life Consortium http://www.boldsystems.org [70,71]. COI is found between bases 5904 and 7445 in human mtDNA [56]. COI was used initially in the identification of invertebrate species [72-77]. It soon became the locus of choice in forensic entomology to identify the beetle larvae on a corpse $[78,79]$. As this one locus could identify these species, it was used more widely with the aim of being the locus of choice for identification of all animal species, to the extent that now the COI locus as a Barcode has been proposed for many types of organisms [80-87].

Other gene loci on the mitochondrial genome have been used in species identification. These include the $12 \mathrm{~S}[88,89]$ and $16 \mathrm{~S}$ rRNA loci $[90]$ and the NDH family of genes [91-93]. The D-loop (displacement loop) has been used less in species identification but more in intraspecies identification $[94,95]$. Due to the greater sequence variation at this non-coding locus, it is now being used as a tool for identifying the presence of particular species within mixture of many species $[96,97]$.

\section{Mitochondrial gene loci in species identification}

The process of species identification in forensic science is becoming routine but has not been standardized to one single locus. Regardless of the locus used, the process is similar whereby the unknown, or questioned, sample is analysed by amplifying a section of the gene, predominantly a section of the cyt $b$ gene or the COI gene. 
This polymerase chain reaction (PCR) fragment is then sequenced directly and the DNA sequence is compared to those registered on an open DNA databank such as GenBank [59]. It is unlikely that there will be a reference sample from a known species for direct comparison; hence there is a reliance on DNA sequence data on the database. GenBank currently has over 108 million sequences (as of August 2009) and, therefore, there is a high chance that the unknown sample will match a DNA sequence from a reference sample deposited on the database. If this is the case, and there is a $100 \%$ homology, then there is confidence that the unknown sample is a member of the species to which it matches. Figure 1 shows an example of the match between a sample taken from a shatoosh shawl, woven from the fine under hairs of the Tibetan antelope (P. hodgsonii), to the DNA sequence held on the GenBank database.

The availability of open access DNA sequence database, such as GenBank, has undoubtedly facilitated much scientific research and, in this regard, forensic science and species identification has also benefited. Allied to these benefits there is a certain amount of risk in any investigation, whether forensic or scientific. It is known that there are misidentified sequences on databases such as GenBank. For example, in a study of fungi, it was found that as much as $20 \%$ of the registered sequences may be misidentified [98]. DNA sequences registered with GenBank do not require that the sample comes from a voucher specimen in the first instance [99] as some museum samples considered to be voucher samples have been found to be misidentified [99]. As museum samples are often used as voucher specimens for sequences, a misidentified specimen in a museum may be very well be used as a 'voucher' sample for obtaining sequence data resulting in an erroneous sequence on the database.

Online and public databases are growing at an almost exponential rate. As more sequences are added to the

\begin{tabular}{|c|c|c|c|c|c|}
\hline & 131 & 141 & 151 & 171 & 181 \\
\hline Unknown 1 & \multicolumn{5}{|c|}{ TTGGTTTTACAAATCCTAACAGGCCTATTCCTAGCAATACACTACACATCTGATACAACA } \\
\hline Pantholops & \multicolumn{5}{|c|}{ TTGGTTTTACAAATCCTAACAGGCCTATTCCTAGCAATACACTACACATCTGATACAACA } \\
\hline Ovis & \multicolumn{5}{|c|}{ 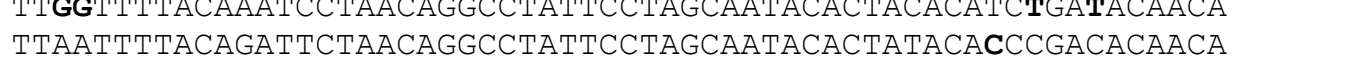 } \\
\hline Rupricapra & \multicolumn{5}{|c|}{ TTAATTTTACAGATCCTAACGGGCCTATTCCTAGCAATACACTACACATCTGACACAACA } \\
\hline Capra & \multicolumn{5}{|c|}{ СTAATTCTACAAATCCTAACAGGCCTATTCCTAGCAATACACTACACATCCGATACAACG } \\
\hline & 182 & 201 & 211 & 231 & 241 \\
\hline Unknown 1 & \multicolumn{5}{|c|}{ ACAGCATTCTCTTCTGTAACCCACATTTGCCGAGATGTTAACTATGGCTGAATTATTCGA } \\
\hline Pantholops & \multirow{2}{*}{\multicolumn{5}{|c|}{ ACAGCATTCTCTTCTGTAACCCACATTTGCCGAGATGTTAACTATGGCTGAATTATTCGA }} \\
\hline Ovis & & & & & \\
\hline Rupricapra & \multicolumn{5}{|c|}{$\begin{array}{l}\text { ACAGCATTCTCCTCTGTAACCCACATTTGCCGAGACGTGAACTATGGCTGAATTATCCGA } \\
\text { ATAGCATCTC }\end{array}$} \\
\hline Capra & \multicolumn{5}{|c|}{ ACAGCATTTTCTTCTGTAACACACATTTGCCGAGACGTAAACTATGGCTGAATTATCCGA } \\
\hline \multicolumn{6}{|l|}{$1 \mathrm{a}$} \\
\hline & Pantholops & Ovis & Rupricapra & Capra & Unknown 1 \\
\hline Pantholops & - & 90.00 & 91.67 & 90.84 & 100.00 \\
\hline Ovis & 12 & - & 91.67 & 90.84 & 90.00 \\
\hline Rupricapra & 10 & 10 & - & 88.33 & 91.67 \\
\hline Capra & 11 & 11 & 14 & - & 90.84 \\
\hline Unknown 1 & 0 & 12 & 10 & 11 & - \\
\hline \multicolumn{6}{|l|}{$1 b$} \\
\hline \multicolumn{6}{|c|}{$\begin{array}{l}\text { Figure } 1 \text { Figure } 1 \text { a and } \mathbf{b} \text { showing a small part of the cyt } \mathbf{b} \text { gene DNA sequence and their differences for four speciesFigure } 1 \text { a shows } \\
\text { bases } 121 \text { - } 241 \text { of the cyt b gene for the Tibetan antelope (Pantholops hodgsonii: accession number AF034724) compared to the mammalian } \\
\text { species with the closest homologies to this part of the sequence; being sheep (Ovis aries: accession AB0068000), the Pyrenean Chamoix } \\
\text { (Rupicapra pyrenaica: accession number AF034726) and a goat (Capra sumatrensis: accession number AY669321). The unknown (or questioned) } \\
\text { sequence comes from a shawl suspected as being from Shatoosh and derived from the Tibetan Antelope. Figure } 1 \mathrm{~b} \text { shows the number of bases } \\
\text { differing between the four species (bottom of the rectangle) and the \% similarity over the } 120 \text { bases. It would be normal to use over } 400 \text { bases } \\
\text { in a similarity search rather than only the } 120 \text { as shown above but this indicates the process used in species testing. }\end{array}$} \\
\hline
\end{tabular}


database and, more importantly, more sequences from the same species are added, it will become easier to identify and remove misidentified sequences. Examples of this phenomenon can be seen in domesticated species (dog, cat, cow, chicken) where there may be up to 100 sequences for the same species for certain gene loci. If any one sequence is highly variable to all the others, then this aberrant sequence will be low on the list of matches. This not only shows the benefit of having multiple sequence data for the same species but also illustrates the potential for a misidentification if there is only one sequence for a particular species at a particular locus. In such a case it would be expected that this sequence would show a high degree of similarity to the DNA sequence from the next closest taxonomic species and, at least, the possibility of contamination from human sequence can be discarded.

If the DNA sequence from the unknown sample shows a $100 \%$ match to the reference sequence for $P$. hodgsonii and an $84 \%$ match to the next closest species, there is confidence that the unknown sample is that of the Tibetan antelope. This confidence that the questioned sample came from the Tibetan antelope and not any other species assumes: (1) that all species are held on the database and there is not another species of the same DNA sequence yet to be analysed; (2) all members of the Tibetan antelope have the same DNA sequence as that registered on GenBank (there is no intraspecies variation); and (3) the sequence data for the next closest match (in Figure 1 this is the goat) is also representative for this species and no members of this species have, by chance, the same sequence as that of the questioned sample. These three assumptions affect the confidence of species identification in any subsequent report.

Until recently, there had been no study to quantify intraspecies variation within the loci used in species identification. Such a study would address the above assumptions and provide a value for the confidence associated with a $100 \%$ match. It would also address the problem associated with a $99 \%$ or less match, in order to determine if any sequence variation could be due to intraspecies variation.

In the case of cyt $b$ and COI, it is generally the practice to amplify a section of the genes for sequence analysis. Further, many of the samples examined are from material that may be at trace level, have many inhibitors to the PCR process present and be highly degraded. In the case of cyt $b$ the section of the gene used is, typically, the first 400 bases [54,100-102] and in the case of COI a fragment of approximately 600 bases is used and no less than 500 base in length [103].

The primer sets that amplify a section of the cyt $b$ gene were initially used by Pääbo et al. [101] and adapted by Kocher et al. [104] and later by Hseih et al. [100].
These primer sets were originally designed based on the human mitochondrial sequence [56,101]. Only later were they aligned with many cyt $b$ gene DNA sequences and it was determined that there was high homology for many species. The aim was to develop a primer pair that would work on most, if not all, species regardless of their taxonomic order. Validation studies were based predominantly on using the primer sets to amplify numerous samples, sequence the PCR product, and compare to either sequence data on GenBank or from in-house sequence data. The universal primer sets for COI were designed by Folmer et al. [105] before being adopted by the Consortium for Barcode of Life.

\section{Cyt b and COI intraspecific and interspecific variations}

For some time there has been a debate as to which of the cyt $b$ or COI loci is the best gene for forensic species identification [106]. Advocates for each gene claim that their gene is better at identification of species but, until recently, there have not been any studies that could apply statistical confidences to sequence comparisons.

There are suggestions as to the levels of interspecific and intraspecific variation that should be expected given for each gene [82,107]. These values are generally based on a Kimura 2-parameter model (K2P) where the estimation of the number of nucleotide substitutions per site takes into account the different rates of transitions and transversions [108].

When the K2P model is used, authors generally state that intraspecifc variation is in the range of $<2-3 \%$ (7.93\% between and $0.43 \%$ within bird species for COI [82]; $5.7 \%$ between and $1.5 \%$ within Stenella species for cyt $b$ [54]). When anomalies arise these are interpreted as hidden or cryptic species [82], although these cryptic species may be based on levels of intraspecific variation from as few as two individuals [109]. This particular example relates to a study on North America bird species.

A study by Kartavtsev and Lee [110] investigated the nucleotide diversity between cyt $b$ and COI at the population, genus and species levels. They analysed a wide range of vertebrate and invertebrate species but did not separate their results into different Classes and amalgamated all results. They determined that the closer any two samples were based on taxonomy, the closer they would be genetically, based on $p$-distance (similar to $\mathrm{K} 2 \mathrm{P}$ but there is no distinction between the probabilities for transitions or transversions; Figure 2) [110].

The study by Kartavtsev and Lee [110] shows that suggested values for both genes appear to be correct. However, it is clear to see that there is overlap within $\mathrm{COI}$ of intraspecific variation and interspecific variation with sibling species (Figure 2). 


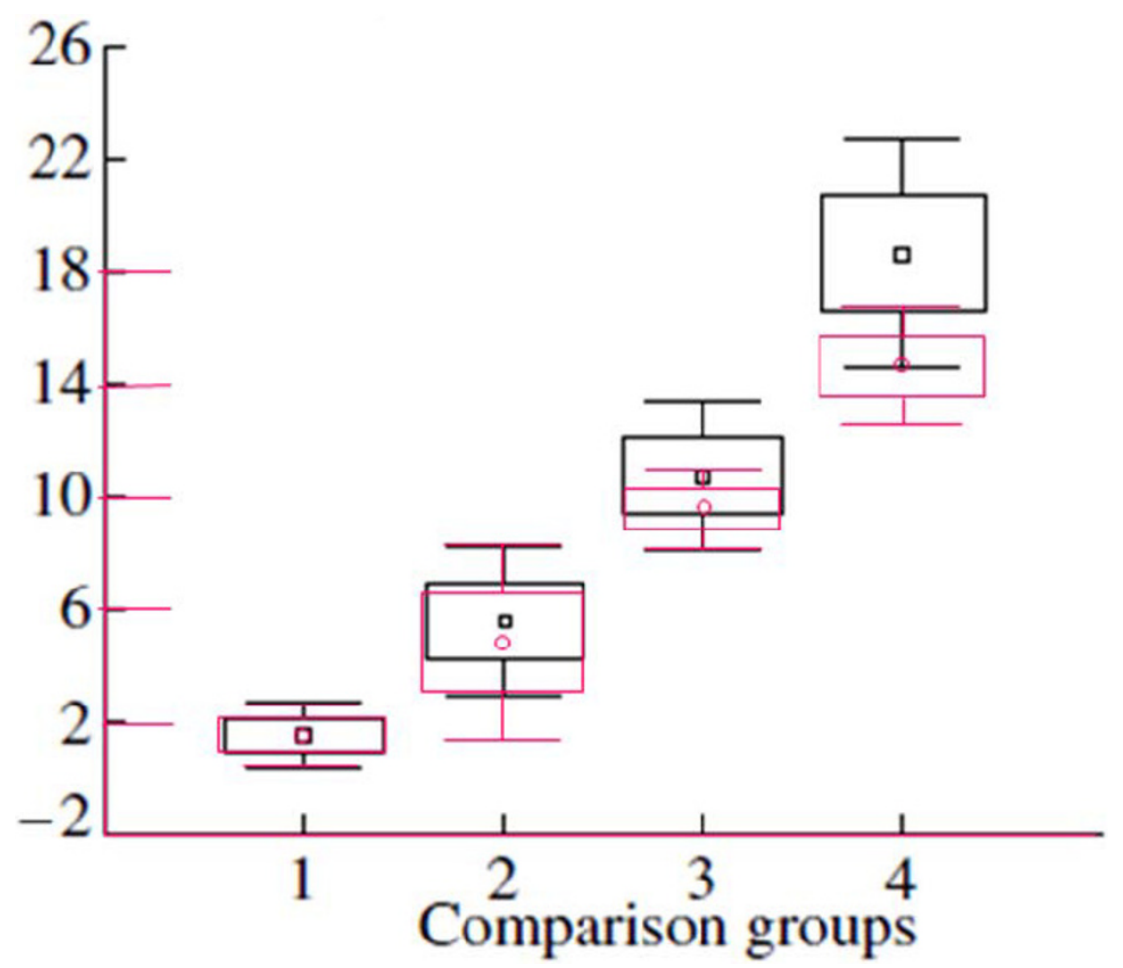

Figure 2 An illustration of the variation on the $P$ distances for both the cyt $b$ (in black) and the COI (in red) gene loci using different taxonomic animal groups. Group 1 is variation within a species; group 2 is variation between sibling species; group 3 is variation between species within the same genus; and group 4 is the variation between species of different genera but within the same Family. The central square indicates the mean, the larger box the standard error $(\mathrm{SE}) \pm 1.00$ and the bars either side of the boxes represent the SE \pm 1.96 . This graph has been adapted from that of Kartavtsev and Lee [108].

A recent study by Tobe et al. [106,111], investigating only the Class Mammalia, refined these results further (for that Class) and derived a method to assign statistical confidence to sequence comparisons. In this study, the cyt $b$ and COI gene sequences were compared for 217 different Mammalian species to assess interspecific variation and 945 human, 130 domestic cattle and 35 domestic dogs to assess intraspecific variation [111]. These data indicated a gap between the greatest observed intraspecific variation (1.5\%) to the closest interspecific variation (2.5\%), based on $\mathrm{K} 2 \mathrm{P}$ values. A threshold can be applied given these data of a predicted maximum inter and intraspecific variation [111]. Both gene comparisons contained K2P values falling below $1.5 \%-2.5 \%$ that, according to the sequence data, belonged to separate species, but these tended to be between sub-species or species with debated taxonomy [111].

By combining all data sets together close to 1 million $\mathrm{K} 2 \mathrm{P}$ comparisons were made. As all sequence information was known, those comparisons between species and within species was known. From that data, Tobe et al. [111] were able to determine the rates of true positives, true negatives, false positives and false negatives at three different threshold values. Their results indicated that although both genes are similar in their discriminating power to separate species, cyt $b$ performed better than did COI [111]. A K2P threshold of 1.5 showed that for COI the false positive rate was $4.85 \times 10^{-4}$ and the positive predictive value was 0.9995 , whereas for cyt $b$ the false positive rate was $2.02 \times 10^{-4}$ and the positive predictive value was 0.9998 [111]. These data indicate that both loci give a high degree of confidence in identification if the data falls within the intraspecific boundary but that there is an even lesser chance of a misidentification using cyt $b$.

As a further test of the two genes, Tobe et al. [111] constructed phylogenetic trees using the sequence data for each gene. They found that, no matter which tree building method was used, some species were always misplaced. Overall, the cyt $b$ gene gave a more accurate reconstruction of Mammalian phylogeny at the Super Order, Order and Family levels than did COI [111].

Further testing for other Classes of organisms needs to be undertaken in order that any significance can be assigned to sequence comparisons. It is likely that the 
levels of intraspecific variation could be much greater in other, older, classes of organisms such as sharks or crocodiles.

\section{Reporting of results - current and future}

In the absence of knowing about intraspecies and interspecies variation there is a limit to the confidence that can be reported as the outcome of a sequencing test to determine species. Currently, if there is a match with $100 \%$ homology between the questioned and reference sequence, there are two possibilities. Either the questioned sample is from the species that it matches or it matches by chance and comes from a species unknown that just happens to have the same DNA sequence as the questioned sample.

If there is not a $100 \%$ homology to any sequence on the database but there is a $99.5 \%$ homology to a sequence with two base differences between the two sequences over a total length of 400 bases and the next closest species has a 96\% homology, then there are two most likely possibilities. Either (1) the questioned sample comes from the same species as that with a $99.5 \%$ homology and the differences are due to intraspecific variation or (2) it comes from an unknown but closely related species, with a $99.5 \%$ sequence match that has not been documented on the database.

However, many reporting this type of data would consider the possibility of such high intraspecies variation, such as exhibiting up to $96 \%$ similarity for a gene locus like cyt b or COI, is highly unlikely such that the only credible alternative is that the questioned sample is that from the species with the $99.5 \%$ homology. This is merely an assumption and can best be supported by studies on intraspecific variation.

With knowledge of intraspecific and interspecific variation detailed in the section above, the three scenarios above can be addressed with a probability. In all mammalian species examined there was a clear gap between intraspecies variation and interspecies variation. A false positive and false negative figure can be quoted allowing the confidence that a questioned sample is a member of the species to which it matches with a $99.5 \%$ homology.

The method of species testing is currently based on the sequence comparison of one mitochondrial locus: predominantly either the cyt $b$ or COI locus. New methods of DNA sequencing open the prospect of sequencing whole genomes [112-114]. Any discussion over which of the two loci is more informative would no longer be valid as, instead of only 400 bases used in comparisons, 1000s of bases can be identified and compared. Validation studies are required in order to ensure that any sequence used in species identification still permits interspecies identification with a clear and unambiguous separation between one species and the next closest.

\section{Acknowledgements}

The authors wish to acknowledge the help of Dr Elaine Kellett for her assistance with Figure 2 and for proof reading the text of the manuscript.

\section{Author details}

${ }^{1}$ South Australia Justice Chair in Forensic Science, School of Biological Sciences, Flinders University, Adelaide, South Australia, Australia. ${ }^{2}$ Centre for Forensic Science, WestChem, University of Strathclyde, Glasgow, UK.

\section{Authors' contributions}

The review was written with equal intellectual in-put by both authors.

\section{Competing interests}

The authors declare that they have no competing interests.

Received: 15 January 2010 Accepted: 13 January 2011

Published: 13 January 2011

\section{References}

1. Christy B: Wildlife Smuggling: Why Does Wildlife Crime Reporting Suck? The Huffington Post 2010 [http://www.huffingtonpost.com/2010/01/04/ wildlife-smuggling-why-do_n_410269.html].

2. Sellar JM: In Illegal trade and the Convention on International Trade in Endangered Species of Wild Fauna and Flora (CITES), in Wildlife Forensic Investigation. Edited by: Linacre AMT. London: Taylor and Francis; 2009:11-18.

3. Li YM, Gao Z, Li X, Wang S: Illegal wildlife trade in the Himalayan region of China. Biodiversity Conservation 2000, 9(7):901-918.

4. World Wildlife Fund: Tiger: Overview. 2010 [http://www.worldwildlife.org/ species/finder/tigers/index.html].

5. Internatonal Rhino Foundation: 2008 [http://www.rhinos-irf.org/black/].

6. Lee $\mathrm{JC}-\mathrm{I}$, Hsieh HM, Huang LH: Ivory identification by DNA profiling of cytochrome b gene. Int J Legal Med 2009, 123(2):117-121.

7. Comstock KE, Ostrander EA, Wasser SK: Amplifying nuclear and mitochondrial DNA from African elephant ivory: A tool for monitoring the ivory trade. Conservation Biol 2003, 17(6):1840-1843.

8. Gupta SK, Thangaraj K, Singh L: A simple and inexpensive molecular method for sexing and identification of the forensic samples of elephant origin. J Forensic Sci 2006, 51(4):805-807.

9. Wasser SK, Clark B, Laurie C: The Ivory Trail. Sci American 2009, 301(1):68-74

10. Wasser SK, Clark Joseph William, Offir Drori, Kisamo Emily Stephen, Celia Mailand, Benezeth Mutayoba, Matthew Stephens: Combating the illegal trade in African elephant ivory with DNA forensics. Conservation Biol 2008, 22(4):1065-1071.

11. Peppin L, McEwing R, Carvalho GR, Ogden R: A DNA-based approach for the forensic identification of Asiatic Black Bear (Ursus thibetanus) in a traditional Asian medicine. J Forensic Sci 2008, 53(6):1358-1362.

12. Brinkman TJ, Hundertmark KJ: Sex identification of northern ungulates using low quality and quantity DNA. Conservation Genetics 2009, 10(4):1189-1193.

13. Jobin RM, Patterson D, Zhang Y: DNA typing in populations of mule deer for forensic use in the Province of Alberta. Forensic Sci Int-Genet 2008, 2(3):190-197.

14. Perez-Espona S, Perez-Barberia F, McLeod JE, Jiggins CD, Gordon IJ, Pemberton JM: Landscape features affect gene flow of Scottish Highland red deer (Cervus elaphus). Molec Ecol 2008, 17(4):981-996.

15. Alacs $E$, Georges A: Wildlife across our borders: a review of the illegal trade in Australia. Australian J Forensic Sci 2008, 40(2):147-160.

16. Linacre A: Application of mitochondrial DNA technologies in wildlife investigations - species identification. Forensic Sci Rev 2006, 18(1):1-8.

17. Ogden R, Dawnay N, McEwing R: Wildlife DNA forensics - bridgging the gap betwen conservation genetics and law enforcement. Endangered Species Res 2009, 9:179-195.

18. Alacs EA, Georges A, FitzSimmons NN, Robertson J: DNA detective: a review of molecular approaches to wildlife forensics. Forensic Sci Med Pathol 2009, 3:180-94.

19. Tobe SS, Linacre A: DNA typing in wildlife crime: recent developments in species identification. Forensic Sci Med Pathol 2010, 6:195-206.

20. Miller Coyle H: In Nonhuman DNA Typing: Theory and Casework Applications. Edited by: Houck M. London: CRC Press; 2008:214, International Forensic Science and Investigation Series. 
21. Linacre A, ed: Forensic Science in Wildlife Investigations International Forensic Science and Investigation Series. Boca Raton: CRC Press; 2009.

22. Butler JM, Schneider PM, Carracedo A: Journal update. Forensic Sci Int Genetics 2010, 4(3):143-144

23. Convention on International Trade in Endangered Species of Wild Fauna and Flora (CITES): What is CITES. 2010 [http://www.cites.org/eng/disc/what. shtml].

24. Convention on International Trade in Endangered Species of Wild Fauna and Flora (CITES): Convention on International Trade in Endangered Species of Wild Fauna and Flora CTES; 1973.

25. Endangered Species Act of 1973: United States of America 1973, 1-48.

26. Wildlife and Countryside Act 1981 in 1981 United Kingdom; 1981, 1-128, Chapt 69.

27. Wildlife and Countryside (Amendment) Act United Kingdom; 1985, 1-4, Chapt 31.

28. Wildlife and Countryside (Amendment) Act 1991 United Kingdom; 1991, 1-2, Chapt 39.

29. Deer Act 1991 United Kingdom; 1991, 1-14, Chapt 54.

30. Conservation of Seals Act 1970 United Kingdom; 1970, 1-6, Chapt 30

31. Protection of Badgers Act 1992 United Kingdom; 1992, 1-12, Chapt 51.

32. Tobe SS, Linacre AMT: A multiplex assay to identify 18 European mammal species from mixtures using the mitochondrial cytochrome $b$ gene. Electrophoresis 2008, 29(2):340-347.

33. Moore JE: A key for the identification of animal hairs. J Forensic Sci Soc 1988, 28(5-6):335-339.

34. Lee JC, Tsai LC, Yang CY, Liu CL, Huang LH, Linacre A, Hsieh HM: DNA profiling of shahtoosh. Electrophoresis 2006, 27(17):3359-3362.

35. Alberts B, et al: Energy Generation in Mitochondria and Chloroplasts. Essential Cell Biology: An Introduction to the Molecular Biology of the Cell London: Garland Publishing; 1998, 407-445, Chapter 13.

36. Pereira SL: Mitochondrial genome organization and vertebrate phylogenetics. Genetics Molec Biol 2000, 23:745-752.

37. Xia $X$, Huang $H$, Carullo M, Betrán E, Moriyama EN: Conflict between Translation Initiation and Elongation in Vertebrate Mitochondrial Genomes. PLOS ONE 2007, 2(2):e227.

38. Clayton DA: Replication of animal mitochondrial-DNA. Cell 1982, 28(4):693-705.

39. Hayashi Jl, Tagashira Y, Yoshida MC: Absence of extensive recombination between interspecies and intraspecies mitochondrial-dna in mammalian-cells. Exp/ Cell Res 1985, 160(2):387-395.

40. Brown WM, George M, Wilson AC: Rapid evolution of animal mitochondrial-DNA. Proc Natl Acad Sci USA 1979, 76(4):1967-1971.

41. Robin ED, Wong R: Mitochondrial-DNA molecules and virtual number of mitochondria per cell in mammalian-cells. J Cell Physiol 1988, 136(3):507-513.

42. Tobe SS, Linacre AMT: A technique for the quantification of human and non-human mammalian mitochondrial DNA copy number in forensic and other mixtures. Forensic Sci Int Genetics 2008, 2(4):249-256.

43. Pfeiffer $H$, Benthaus $S$, Rolf B, Brnkmann B: The Kaiser's tooth. Int J Legal Med 2003, 117(2):118-120.

44. Ginther $C$, Isseltarvern L, King MC: Identifying individuals by sequencing mitochondrial-DNA from teeth. Nature Genetics 1992, 2(2):135-138.

45. Loreille OM, Degoli TM, Irwin JA, Coble MD, Parsons TJ: High efficiency DNA extraction from bone by total demineralization. Forensic Sci IntGenetics 2007, 1(2):191-195.

46. Anslinger K, Weichhold G, Keil W, Bayer B, Eisenmeger W: Identification of the skeletal remains of Martin Bormann by mtDNA analysis. Int J Legal Med 2001, 114(3):194-196.

47. Parson W: Relevance of mtDNA analysis for forensic applications. Rechtsmedizin 2009, 19(3):183-192.

48. Allen M, Saldeen T, Pettersson U, Gyllensten U: Mitochondrial DNA sequencing of shed hairs and saliva on robbery caps: Sensitivity and matching probabilities. J Forensic Sci 1998, 43(3):453-464.

49. Budowle B, Allard MW, Wilson MR, Chakraborty R: Forensics and mitochondrial DNA: Applications, debates, and foundations. Ann Rev Genomics Human Genetics 2003, 4:119-141.

50. Dissing J, Binladen J, Hansen A, Sejrsen B, Willerslev E, Lynnerup N: The last Viking King: A royal matemity case solved by ancient DNA analysis. Forensic Sci Int 2007, 166(1):21-27.

51. Biesecker LG, Bailey-Wilson JE, Ballantyne J, Baum H, Bieber FR, Brenner C, Budowle B, Butler JM, Carmody G, Conneally PM, et al: EPIDEMIOLOGY: enhanced: DNA dentifications after the 9/11 World Trade Center attack. Science 2005, 310(5751):1122-1123.

52. Simon C, Buckley TR, Frat F, Stewart JB, Brecenbach AT: Incorporating molecular evolution into phylogenetic analysis, and a new compilation of conserved polymerase chain reaction primers for animal mitochondrial DNA. Ann Rev Ecol Evolution Systematics 2006, 37(1):545-579.

53. Kuwayama R, Ozawa T: Phylogenetic relationships among European Red Deer, Wapiti, and Sika Deer inferred from mitochondrial DNA sequences. Molec Phylogenetics Evolution 2000, 15(1):115-123.

54. Irwin D, Kocher T, Wilson A: Evolution of the cytochrome b gene of mammals. J Molec Evolution 1991, 32(2):128-144.

55. Kocher TD, Thomas WK, Meyer A, Edwards SV, Pääbo S, Villablanca FX Wilson AC: Dynamics of mitochondrial DNA evolution in animals: amplification and sequencing with conserved primers. Proc Natl Acad Sci USA 1989, 86(16):6196-6200.

56. Anderson S, Bankier AT, Barrell BG, de Bruijn MH, Coulson AR, Drouin J, Eperon IC, Nierlich DP, Roe BA, Sanger F, et al: Sequence and organization of the human mitochondrial genome. Nature 1981, 290(5806):457-465.

57. Tobe SS, Linacre A: A method to identify a large number of mammalian species in the UK from trace samples and mixtures without the use of sequencing. Forensic Sci Int: Genetics Supp/ Series 2008, 1(1):625-627.

58. An J, Lee MY, Min MS, Lee MH, Lee H: A molecular genetic approach for species identification of mammals and sex determination of birds in a forensic case of poaching from South Korea. Forensic Sci Int 2007, 167(1):59-61.

59. Tobe $S$, Linacre A: Species identification of human and deer from mixed biological material. Forensic Sci Int 2007, 169(2-3):278-279.

60. de Pancorbo MM, Castro A, Fernandez-Fernandez I, GonzalezFernandez MC, Martnez-Bouzas C, Cuevas N: Cytochrome b and HVI sequences of mitochondrial DNA to identify domestic animal hair in forensic casework. Int Congress Series 2003, 1239:841-845.

61. Wan QH, Fang SG: Application of species-specific polymerase chain reaction in the forensic identification of tiger species. Forensic Sci Int 2003, 131(1):75-78

62. Wetton JH, Tsang CS, Roney CA, Spriggs AC: An extremely sensitive species-specific ARMs PCR test for the presence of tiger bone DNA. Forensic Sci Int 2004, 140(1):139-145.

63. Tobe SS, Linacre A: Identifying endangered species from degraded mixtures at low levels. Forensic Sci Int: Genetics Supp/ Series 2009, 2(1):304-305.

64. Moore MK, Bemss JA, Rce SM, Quattro JM, Woodley CM: Use of restriction fragment length polymorphisms to identify sea turtle eggs and cooked meats to species. Conservation Genetics 2003, 4(1):95-103.

65. Hsieh HM, Huang LH, Tsai LC, Liu CL, Kuo YC, Hsiao CT, Linacre A, Lee JC: Species identification of Kachuga tecta using the cytochrome $b$ gene. $J$ Forensic Sci 2006, 51(1):52-56.

66. Rohilla MS, Tiwari PK: Restriction fragment length polymorphism of mitochondrial DNA and phylogenetic relationships among five species of Indian freshwater turtles. J App/ Genetics 2008, 49(2):167-182.

67. Meganathan PR, Dubey B, Haque I: Molecular identification of crocodile species using novel primers for forensic analysis. Conservation Genetics 2009, 10(3):767-770.

68. Hsieh HM, Huang LH, Tsai LC, Kuo YC, Meng HH, Linacre A, Lee JC: Species identification of rhinoceros horns using the cytochrome $b$ gene. Forensic Sci Int 2003, 136(1-3):1-11.

69. Gupta SK, Verma SK, Singh L: Molecular insight into a wildlife crime: the case of a peafowl slaughter. Forensic Sci Int 2005, 154(2-3):214-217.

70. Hebert PD, Cywinska A, Ball SL, deWaard JR: Biological identifications through DNA barcodes. Proc Roy Soc B: Biolog Sci 2003, 270(1512):313-321.

71. Borisenko AV, Lim BK, Ivanova NV, Hanner RH, Herbert PDN: DNA barcoding in surveys of small mammal communities: a field study in Suriname. Molec Ecol Res 2008, 8(3):471-479.

72. Meier R, Shiyang K, Vaidya G, Ng PK: DNA barcoding and taxonomy in diptera: A tale of high intraspecific variability and low identification success. Systematic Biology 2006, 55(5):715-728.

73. Janzen DH, Hajibabaei M, Burns JM, Hallwachs W, Remigio E, Hebert PD: Wedding biodiversity inventory of a large and complex Lepidoptera fauna with DNA barcoding. Phil Trans Roy Soc B-Biolog Sci 2005, 360(1462):1835-1845

74. Hajibabaei M, Janzen DH, Burns JM, Hallwachs W, Hebert PD: DNA barcodes distinguish species of tropical Lepidoptera. Proc Natl Acad Sci USA 2006, 103(4):968-971. 
75. Rojo Velsco S, Ståhls G, Pérez Baňón C, Marcos Garcia MA: Testing molecular barcodes: Invariant mitochondrial DNA sequences vs the larval and adult morphology of West Palaearctic Pandasyopthalmus species (Diptera : Syrphidae : Paragini). Eur J Entomol 2006, 103(2):443-458.

76. Smith MA, Woodley NE, Janzen DH, Hallwachs W, Hebert PD: DNA barcodes reveal cryptic host-specificity within the presumed polyphagous members of a genus of parasitoid flies (Diptera : Tachinidae). Proc Natl Acad Sci USA 2006, 103(10):3657-3662.

77. Cywinska A, Hunter FF, Hebert PDN: Identifying Canadian mosquito species through DNA barcodes. Med Vet Entomol 2006, 20(4):413-424.

78. Nelson LA, Wallman JF, Dowton M: Using COI barcodes to identify forensically and medically important blowflies. Med Vet Entomol 2007, 21(1):44-52.

79. Mitchell A: DNA barcoding demystified. Australian J Entomol 2008, 47:169-173.

80. Smith MA, Poyarkov NA, Hebert PDN: CO1 DNA barcoding amphibians: take the chance, meet the challenge. Molec Ecol Res 2008, 8(2):235-246.

81. Holmes $B H$, Steinke D, Ward RD: Identification of shark and ray fins using DNA barcoding. Fisheries Res 2009, 95(2-3):280-288.

82. Hebert PDN, Stoeckle MY, Zemlak TS, Francis CM: Identification of birds through DNA barcodes. Plos Biol 2004, 2(10):1657-1663.

83. Yoo HS, Eah JY, Kim JS, Kim YJ, Min MS, Paek WK, Lee H, Kim CB: DNA barcoding Korean birds. Molec Cells 2006, 22(3):323-327.

84. Tavares ES, Baker AJ: Single mitochondrial gene barcodes reliably identify sister-species in diverse clades of birds. BMC Evolutionary Biol 2008, 8:81.

85. Lohman DJ, Prawiradilaga DM, Meier R: Improved COI barcoding primers for Southeast Asian perching birds (Aves: Passeriformes). Molec Ecol Res 2009, 9(1):37-40

86. Wong EHK, Shivji MS, Hanner RH: Identifying sharks with DNA barcodes: assessing the utility of a nucleotide diagnostic approach. Molec Ecol Res 2009, 9:243-256.

87. Huang J, Qin Xu, Zhen Jun Sun, Gui Lau Tang: Identifying earthworms through DNA barcodes. Pedobiologia 2007, 51(4):301-309.

88. Balitzki-Korte B, Anslinger K, Bartsch C, Rolf B: Species identification by means of pyrosequencing the mitochondrial $12 \mathrm{~S}$ rRNA gene. Int J Legal Med 2005, 119(5):291-294.

89. Melton $\mathrm{T}, \mathrm{Holland} \mathrm{C}$ : Routine forensic use of the mitochondrial $12 \mathrm{~S}$ ribosomal RNA gene for species identification. J Forensic Sci 2007, 52(6):1305-1307.

90. Mitani T, Akane A, Tokiyasu T, Yoshimura S, Okii Y, Yoshida M: Identification of animal species using the partial sequences in the mitochondrial $16 \mathrm{~S}$ rRNA gene. Leg Med (Tokyo) 2009, 11(Suppl 1):S449-S450.

91. Schwenke PL, Rhydderch JG, Ford MJ, Marshall AR, Park LK: Forensic identification of endangered Chinook Salmon (Oncorhynchus tshawytscha) using a multilocus SNP assay. Conservation Genetics 2006, 7(6):983-989.

92. Junqueira $A C$, Lessinger $A C$, Torres $T$, da Silva FR, Vettore $A L$, Arruda $P$, Azeredo Espin AM: The mitochondrial genome of the blowfly Chrysomya chloropyga (Diptera : Calliphoridae). Gene 2004, 339:7-15.

93. Mayer F, Dietz C, Kiefer A: Molecular species identification boosts bat diversity. Frontiers Zoology 2007, 4(1):4.

94. Clifford SL, Anthony NM, Bawe-Johnson M, Abernethy KA, Tutin CE, White $L$, Bermejo M, Goldsmith ML, McFarland K, Jeffery KJ, et al: Mitochondrial DNA phylogeography of western lowland gorillas (Gorilla gorilla gorilla). Molec Ecol 2004, 13(6):1551-1565.

95. Zhang W, Zhang Z, Shen F, Hou R, Lv X, Yue B: Highly conserved D-looplike nuclear mitochondrial sequences (Numts) in tiger (Panthera tigris). J Genetics 2006, 85(2):107-116.

96. Pun KM, Albrecht C, Castella V, Fumagalli L: Species identification in mammals from mixed biological samples based on mitochondrial DNA control region length polymorphism. Electrophoresis 2009, 30(6):1008-1014.

97. Fumagalli L, Cabrita CJ, Castella V: Simultaneous identification of multiple mammalian species from mixed forensic samples based on mtDNA control region length polymorphism. Forensic Sci Int: Genetics Supp/ Series 2009, 2(1):302-303.

98. Nilsson RH, Ryberg M, Kristiansson E, Abarenkov K, Larsson KH, Kõljalg U: Taxonomic Reliability of DNA Sequences in Public Sequence Databases: A Fungal Perspective. PLOS ONE 2006, 1:e59.

99. Zhang G, Strasser BJ: Specimens Versus Sequences. Science 2009, 323(5922):1672.
100. Hsieh HM, Chiang HL, Tsai LC, Lai SY, Huang NE, Linacre A, Lee JC: Cytochrome $b$ gene for species identification of the conservation animals. Forensic Sci Int 2001, 122(1):7-18

101. Pääbo S, Gifford JA, Wilson AC: Mitochondrial DNA sequences from a 7000-year old brain. Nucleic Acids Res 1988, 16(20):9775-9787.

102. Parson W, Pegoraro K, Niederstätter H, Föger M, Steinlechner M: Species identification by means of the cytochrome b gene. Int J Legal Med 2000 114(1):23-28

103. Hebert PDN, Ratnasingham S, de Waard JR: Barcoding animal life: cytochrome c oxidase subunit 1 divergences among closely related species. Proc Roy Soc Lond Series B: Biolog Sci 2003, 270(Suppl 1):S96-S99.

104. Kocher TD, Thomas WK, Meyer A, Edwards SV, Pääbo S, Villablanca FX, Wilson AC: Dynamics of mitochondrial-DNA evolution in animals amplification and sequencing with conserved primers. Proc Natl Acad Sci USA 1989, 86(16):6196-6200.

105. Folmer O, Black M, Hoeh W, Lutz R, Vrijenhoek R: DNA primers for amplification of mitochondrial cytochrome c oxidase subunit I from diverse metazoan invertebrates. Molec Marine Biol Biotech 1994, 3:294-299.

106. Tobe SS, Kitchener A, Linacre A: Cytochrome b or cytochrome $c$ oxidase subunit I for mammalian species identification - an answer to the debate. Forensic Sci Int: Genetics Supp/ Series 2009, 2(1):306-307.

107. Su B, Wang YX, Lan H, Wang W, Zhang Y: Phylogenetic study of complete cytochrome b genes in musk deer (Genus Moschus) using museum samples. Molec Phylogen Evol 1999, 12(3):241-249.

108. Nei M, Kumar S: Molecular Evolution and Phylogenetics New York: Oxford University Press; 2000, 333.

109. Moritz C, Cicero C: DNA Barcoding: Promise and Pitfalls. PLoS Biol 2004, 2(10):e354.

110. Kartavtsev YP, Lee JS: Analysis of nucleotide diversity at the cytochrome $\mathrm{b}$ and cytochrome oxidase 1 genes at the population, species, and genus levels. Russian J Genet 2006, 42(4):341-362.

111. Tobe SS, Kitchener AC, Linacre AMT: Reconstructing mammalian phylogenies: a detailed comparison of the cytochrome $b$ and cytochrome oxidase subunit I mitochondrial genes. PLOS ONE 2010 [http://dx.plos.org/10.1371/journal.pone.0014156].

112. Li R, Zhu H, Ruan J, Qian W, Fang X, Shi Z, Li Y, Li S, Shan G, Kristiansen K, et al: De novo assembly of human genomes with massively parallel short read sequencing. Genome Res 2010, 20(2):265-272

113. Haussler D, O'Bren SJ, Ryder OA: Genome 10K: a proposal to obtain whole-genome sequence for 10000 vertebrate species. J Heredity 2009, 100(6):659-674.

114. Smith AM, Heisler LE, Mellor J, Kaper F, Thompson MJ, Chee M, Roth FP Giaever G, Nislow C: Quantitative phenotyping via deep barcode sequencing. Genome Res 2009, 19(10):1836-1842.

doi:10.1186/2041-2223-2-2

Cite this article as: Linacre and Tobe: An overview to the investigative approach to species testing in wildlife forensic science. Investigative Genetics 2011 2:2

\section{Submit your next manuscript to BioMed Central and take full advantage of:}

- Convenient online submission

- Thorough peer review

- No space constraints or color figure charges

- Immediate publication on acceptance

- Inclusion in PubMed, CAS, Scopus and Google Scholar

- Research which is freely available for redistribution

Submit your manuscript at www.biomedcentral.com/submit
C Biomed Central 